\title{
Compromised collaborations: food, fuel, and power in transnational food security governance
}

\section{Matthew Canfield}

To cite this article: Matthew Canfield (2019): Compromised collaborations: food, fuel, and power in transnational food security governance, Transnational Legal Theory, DOI: 10.1080/20414005.2019.1571772

To link to this article: https://doi.org/10.1080/20414005.2019.1571772

\section{曲 Published online: 10 Feb 2019.}

Submit your article to this journal

\section{View Crossmark data $\asymp$}




\title{
Compromised collaborations: food, fuel, and power in transnational food security governance
}

\author{
Matthew Canfield \\ Assistant Professor, Program in Law, Politics, and Society, Drake University, Des Moines, lowa, \\ USA
}

\begin{abstract}
This essay analyses how the relation between food and fuel shapes the practice of collaborative food governance. Dominant explanations for the persistence of global hunger often point to the influence of political-economic inequalities on the production, distribution, and governance of global food. The causes of the 2007-2008 global food crisis, however, suggest the need to examine the entanglements between food and other forms of ecological extraction. I draw on the concept of 'energopolitics' to demonstrate how changing material processes of energy extraction condition the calculative logics through which transnational food governance is constituted. An energopolitical analysis, I argue, illuminates how collaborative food governance supresses the conflict between food and fuel that it was developed to mediate. In an era of climate change, such an approach reveals the links between food and broader struggles over carbon-fuelled inequalities.
\end{abstract}

KEYWORDS Food governance; biofuels; energy; political economy; political ecology

The 2007-2008 global food crisis was a powerful reminder of the critical role that food production and provisioning play in constituting transnational normative orders. Just as ending global hunger, or what is now called 'food security', played an important role in the formation of the post-World War II international order, recent food crises have served as contentious conflicts that have challenged hegemonic regulatory regimes. The 2007-2008 global food crisis was one such moment of transformation. The regulatory failure pushed 100 million more people into hunger and caused food riots in over thirty countries. ${ }^{1}$ As states, transnational social movements, corporations, and international institutions struggled for control, a new paradigm of collaborative transnational food security governance emerged. Today, the practice of collaborative food governance offers a critical site through which to analyse changing forms of power amidst a shifting political economic and ecological context.

\footnotetext{
CONTACT Matthew Canfield matthew.canfield@drake.edu

${ }^{1}$ Food and Agriculture Organization of the United Nations, \& World Food Program, The State of Food Insecurity in the World 2009, (FAO 2009), online: <http://www.fao.org/3/a-i0876e.pdf>; Raj Patel and Philip McMichael, 'A Political Economy of the Food Riot' (2009) 32 Review (Fernand Braudel Center) 9-35.

(c) 2019 Informa UK Limited, trading as Taylor \& Francis Group
} 
Most accounts of food security politics point to political-economic asymmetries as the driving factor shaping the production, distribution, and governance of global food. These asymmetries were particularly manifest in the negotiation of the Agreement on Agriculture and other global trade agreements, which have perpetuated hunger among small-scale producers and rural peoples in the developing world. ${ }^{2}$ The inclusion of civil society and other actors into new arenas and global decision-making processes thus offered hope of democratizing global food governance. Yet though multi-stakeholder and collaborative arenas of global food governance have been designed to offer a more level playing field, inequalities persist. Analysts of global food security governance are thus becoming increasingly disillusioned with collaborative and multi-stakeholder paradigms of governance. ${ }^{3}$ Such failures to produce more equitable outcomes even through collaborative models suggests the need to look beyond 'capitalocentric' political economic accounts of power within transnational governance processes.

Indeed, the causes of the 2007-2008 global food crisis, point to a set of ecological entanglements overlooked by political economic accounts. While several factors converged to cause the crises, concern over energy was a key factor; rising oil prices and concurrent increased biofuel demand were major causes of the global food crisis. ${ }^{4}$ As crops whose starches, sugars, oils, and cellulose can be harvested to produce carbon energy, biofuels have been pursued with an increasing zeal by powerful states seeking to wean themselves from fossil fuels while maintaining their national energy security. As states replaced food crops with fuel crops, however, they limited global food stocks, causing food prices to skyrocket. ${ }^{5}$ The crisis thus revealed the significance of the 'food-fuel nexus' - a mutually dependent relationship that had also been at the centre of the 1973-1974 global food crisis. The causal role of

\footnotetext{
${ }^{2}$ Carmen G Gonzalez, 'Institutionalizing Inequality: The WTO Agreement on Agriculture, Food Security, and Developing Countries' (2002) 27 Columbia Journal of Environmental Law 433; Jennifer Clapp, 'World Hunger And The Global Economy: Strong Linkages, Weak Action' (2014) 67 Journal of International Affairs 1.

${ }^{3}$ Nora McKeon, 'Are Equity and Sustainability a Likely Outcome When Foxes and Chickens Share the Same Coop? Critiquing the Concept of Multistakeholder Governance of Food Security' (2017) 14:3 Globalizations 379.

${ }^{4}$ Those concerned with the interactions between food and fuel often prefer the term 'agrofuels,' over 'biofuels.' The term 'biofuels' is promoted by powerful states, transnational agri-business corporations, and other associated interest groups in an effort to frame the production of fuel crops as a sustainable alternative to fossil-fuels. Those who use the term 'agrofuels' seek to emphasize the political drivers of land use change and the resulting impact on economic inequality and food insecurity. As Deitz and others note, "the term agrofuels alludes to agro-industrial agriculture and its inherent commodification of nature and to the modernization and industrialization of rural areas with all impact on social relations and ecological conditions." See Kristina Dietz and others, The Political Ecology of Biofuels (Routledge, 2014) 3. While I prefer the term 'agrofuels', I use the term 'biofuels' throughout this article for consistency, since it served as the dominant framing of the negotiation within the Committee on World Food Security, which I analyse later in this article.

${ }^{5}$ Mark W Rosegrant. (International Food Policy Research Institute), Biofuels and Grain Prices: Impacts and Policy Responses (2008), online: <http://ebrary.ifpri.org/utils/getfile/collection/p15738coll2/id/10350/ filename/10351.pdf>.
} 
the food-fuel nexus in both crises therefore suggest that while political economic inequalities certainly play a key role in transnational food governance, understanding the contemporary operation and exercise of power requires attending to the energetic foundations of power.

This brief article reassesses how competition over energy shapes transnational food security governance. Building on recent studies that have located energy, rather than capital, at the core of global relations of power, this article proposes that the recognition of the food-fuel nexus necessitates a new conceptual framework to assess the power exercised both within global food governance and across transnational legal processes. In analysing the production and practice of transnational food security governance, I draw on the concept of 'energopower'-the power generated and exercised 'over and through energy. ${ }^{6}$ In applying this framework to analyse transnational food security governance, I suggest that the development and practice of collaborative governance serves to maintain carbon-fuelled inequalities as food and fuel increasingly compete over land. By assuming that this conflict can be resolved through consensus, without recognising energy-driven power asymmetries, multi-stakeholder processes supress the conflict they have been deployed to mediate. In an era when climate change threatens humanity's survival, an energopolitical lens thus connects conflicts over food and agriculture with broader struggles over ecological extraction.

Part I offers a short history of the rise of transnational food security governance, emphasising the often-overlooked role of the food-fuel nexus. I describe how the biofuel-caused food crisis of 2007-2008 led to a transformation of the UN Committee on World Food Security (CFS) from an intergovernmental institution to a collaborative, multi-stakeholder arena. In Part II, I draw on ethnographic fieldwork within the CFS to analyse the negotiation of the Recommendations on Biofuels and Food Security. I describe how unequal power relations throughout the process profoundly shaped the outcomes of the negotiations. While most accounts suggest that such a failure of collaboration is the product of inadequately designed processes to account for asymmetries of bargaining power (which are themselves considered a reflection of inequalities of capital), in Part III, I offer an alternative account, focusing on the role of energopower. In this section, I develop a thumbnail sketch of the way that the food-fuel nexus has historically shaped shifting ideologies of transnational regulation. I suggest that collaborative governance has arisen in response to the failure of previous calculative logics of energy within transnational legal arrangements, but like previous regulatory ideologies seeks to depoliticise the food-fuel nexus in order to maintain dominant distributions of power. Ultimately, through this energopolitical analysis of global food

\footnotetext{
${ }^{6}$ Dominic Boyer, 'Energopower: An Introduction' (2014) 87:2 Anthropological Quarterly 309, 323.
} 
governance, this article contributes to this Symposium by situating the study of transnational food governance within broader struggles over ecological extraction in an age of climate change.

\section{The rise of transnational food security governance}

Contemporary transnational food security governance has its roots in the world food crisis of 1972-1974. The crisis' immediate cause was a large global grain trade, a détente, between the Soviet Union and the United States (US) after the Soviet Union faced a massive crop failure. The trade created a sudden shortage on global grain markets that caused cereal prices to skyrocket. ${ }^{7}$ Yet underlying the crisis was an oil shock that caused the US, then the world's main guarantor of global food security, significant anxiety. Since the development of 'scientific farming' in the late nineteenth and early twentieth centuries, industrial food production had become dependent on cheap and easy access to fuel for agricultural inputs such as fertiliser and pesticides as well as for transport. ${ }^{8}$ The US also actively promoted these fossil-fuel dependent forms of agro-industrial production in Latin America and South Asia through the Green Revolution. The crisis illuminated the mutual dependence of states on food and fuel and immediately produced a political struggle over global food regulation. Standing before the UN General Assembly in 1974, US President Gerald Ford made the link between food and energy clear, when he declared:

The food and oil crises demonstrate the extent of our interdependence... Energy is required to produce food and food to produce energy-and both to provide a decent life for everyone. A global strategy for food and energy is urgently required. ${ }^{9}$

In the aftermath of the crisis, participants in the 1974 World Food Summit agreed to form the World Food Council (WFC) to coordinate the UN's response to the global food crisis as well as a standing FAO Committee on World Food Security. Soon after the crisis, however, to cope with both increasing global competition and the ongoing threat of energy insecurity, the US embraced a more market-oriented approach to relieve its agricultural surpluses. It sought to limit the WFC's mandate and, along with other OECD countries, to dismantle the UN Food and Agriculture Organization's (FAO) authorities, reorganising them to allow for greater control and oversight by donor countries. ${ }^{10}$ Rather than building an international architecture to monitor global food stocks and manage global food markets, the US and

\footnotetext{
${ }^{7}$ Harriet Friedmann, 'The Political Economy of Food: A Global Crisis' (1993) New Left Review 29.

${ }^{8}$ Deborah Fitzgerald, Every Farm a Factory: The Industrial Ideal in American Agriculture (Yale University Press, 2010).

${ }^{9}$ The New York Times, Transcript of President Ford's Address to Session of U.N. General Assembly (1974), online: <https://www.nytimes.com/1974/09/19/archives/transcript-of-president-fords-address-tosession-of-un-general.html>.
} 
other grain exporting countries became increasingly focused on trade. International finance institutions and the Global Agreement on Tarriffs and Trade became the primary arenas driving global food governance. By 1995, the Washington Consensus emerged as the dominant economic ideology and the Agreement on Agriculture was signed, unevenly opening up formerly protected agricultural markets.

The penetration of neoliberalism in global food and agriculture may have helped to manage the contradictions of the US-dominated global 'food regime' of the post-World War II period, but it did not address concerns about energy security. ${ }^{11}$ In the 1970 s, the mutually dependent relationship between food and fuel grew increasingly contradictory. In response to efforts by the Organization of Petroleum Exporting Countries' (OPEC) to take greater control over their natural resources, powerful oil dependent states began to turn to biofuels as a fuel additive and source of transport fuel. As concerns about foreign energy dependence, 'peak oil', and fossil fuel-caused climate change grew increasingly salient, the US, Canada, the European Union, Brazil and other countries began to implement biofuel mandates and subsidies to stimulate a market for renewable fuels. ${ }^{12}$ By the early 2000s, the global biofuel market had rapidly expanded and US imports tripled. ${ }^{13}$ Ethanol output grew from 16.9 to 72.0 billion litres and biodiesel output grew from 0.8 to 14.7 billion litres. ${ }^{14}$ In 2008 alone, $16 \%$ of the world's soy crop, $18 \%$ of the world's sugar cane, and $11 \%$ of the world's corn harvest went into biofuel production. ${ }^{15}$ Consequently, food and fuel crops were in direct competition for land.

In the aftermath of the biofuel-caused food crisis 2007-2008, multiple actors and institutions began to vie for authority over food and agricultural governance. In the meantime, a powerful set of transnational agrarian

\footnotetext{
${ }^{10}$ Nora McKeon, Food Security Governance: Empowering Communities, Regulating Corporations (Routledge, 2015) 16.

${ }^{11}$ Harriet Friedmann and Philip McMichael describe 'food regimes' as 'rule-governed structure[s] of production and consumption of food on a world scale.' They identify three food regimes: the colonial food regime dominated by the United Kingdom (1870-1930s), a 'mercantile industrial' food regime dominated by the United States (1940s-1970s), and a third regime starting in the 1970s that has sometimes been called the 'corporate food regime' or the 'corporate-environmental regime.' The food regime framework reveals how internal contradictions and struggles for control within each regime has facilitated shifting arrangements of global agricultural power. See Philip McMichael, 'A Food Regime Genealogy' (2009) 36:1 The Journal of Peasant Studies 139; Harriet Friedmann, 'From Colonialism to Green Capitalism: Social Movements and Emergence of Food Regimes' (2015) 11 New Directions in the Sociology of Global Development 227.

${ }^{12}$ For an empirical analysis of biofuel mandates see: Timothy Wise and Emily Cole, 'Global Development and Environment Institute, Mandating Food Insecurity: The Global Impacts of Rising Biofuel Mandates and Targets' (2015), GDAE Working Paper No. 15-01.

${ }^{13}$ See Gustavo de LT Oliveira, Ben McKay and Christina Plank, 'How Biofuel Policies Backfire: Misguided Goals, Inefficient Mechanisms, and Political-Ecological Blind Spots' (2017) 108 Energy Policy 765.

${ }^{14}$ Giovanni Sorda, Martin Banse and Claudia Kemfert, 'An Overview of Biofuel Policies across the World' (2010) 38 Energy Policy 6977, 6977.

${ }^{15}$ Robert Bailis and Jennifer Baka, 'Constructing Sustainable Biofuels: Governance of the Emerging Biofuel Economy' (2011) 101:4 Annals of the Association of American Geographers 827, 830.
} 
movements had formed to oppose neoliberalism in agriculture. These movements, along with a cadre of international NGOs, began to demand inclusion into decision-making processes. They argued that the FAO and the CFS, the institution in which they had had the greatest access, were the most appropriate arenas for global food governance. With the FAO's authority waning, it initiated a reform process that would lead the CFS to become the most inclusive global food security policy space, in an attempt to subsume competing initiatives. $^{16}$

Although participants of the CFS approached the reform process with very different visions of 'inclusivity', multi-stakeholder partnerships offered a popular template for governance. Multi-stakeholder initiatives emerged in the 1990s in response to both neoliberal challenges to the hierarchical 'command and control' paradigm of regulation as well as demands for participation from below, particularly in the domain of environmental politics. ${ }^{17}$ Grounded in a pragmatic and collaborative approach to problem-solving, multi-stakeholder initiatives are based on the primary assumption that 'more participation and deliberation by affected groups will generate more effective collective problem-solving. ${ }^{18}$ Proponents of collaborative governance suggest that non-hierarchical, deliberative, and consensus-based processes can produce 'win-win' solutions for global conflicts.

In the context of struggles between food and fuel, collaborative forms of governance suggested a compromise could be reached between competing demands and social values. Hence, in response to the biofuel-caused food crisis, the CFS adopted a complex hybrid structure that draws together intergovernmental decision-making, multi-actor negotiation, and expert guidance. At the same time, different institutional arrangements of collaborative governance proliferated to manage a variety of crop-specific conflicts over biofuels, including the Roundtable on Responsible Palm Oil, Bonsucro (formerly the Better Sugarcane Initiative), the Roundtable on Responsible Soy, and the Roundtable on Sustainable Biomaterials. By drawing on the symbols of participation, inclusion, and consensus, the emerging multi-stakeholder paradigm seemed to offer the promise of greater global democracy. ${ }^{19}$

\footnotetext{
${ }^{16}$ See Christoffersen, Leif E. and others, Food and Agricultural Organization, FAO: The Challenge of Renewal: Report of the Independent External Evaluation of the Food and Agriculture Organization of the United Nations (FAO), (2007), online: <http://www.fao.org/unfao/bodies/IEE-Working-Draft-Report/K0489E. pdf $>$.

17 The language of 'stakeholders' however itself emerged from management strategy. See $\mathrm{R}$ Edward Freeman, Strategic Management: A Stakeholder Approach (Cambridge University Press, 2010).

${ }^{18}$ Karin Bäckstrand, 'Multi-Stakeholder Partnerships for Sustainable Development: Rethinking Legitimacy, Accountability and Effectiveness' (2006) 16 European Environment 290, 295.

${ }^{19}$ As McKeon notes, 'It is in this democratic 'public sphere' that the tendencies represented by the reformed CFS can be situated and-hopefully-reinforced by extending their authority over the economic world.' McKeon (n 10) 202.
} 


\section{The practice of collaborative food governance}

Biofuels were one of the key issues that the CFS sought to address in its reform. However, they proved deeply controversial. ${ }^{20}$ In 2011, when the CFS negotiated a set of recommendations to address food price volatility, civil society walked out because the US and other biofuel producers refused to recognise the impact of biofuels on rising food prices. Two years later, at the fortieth session of the CFS in 2013, the Committee met to develop a set of Policy Recommendations on Biofuels and Food Security (Recommendations), which I observed as part of a multi-year ethnographic project on the CFS.

In the preparatory meetings of the Civil Society Mechanism-the autonomous platform for the coordination of peoples' organisations, social movements, and international NGOs-activists expected the negotiations to be tense. However, because the CFS' mandate is focused on the elimination of hunger and the progressive realisation of the right to food, they hoped to develop a strong statement that prioritised food security over energy extraction and markets. Some participants described the negotiations over the Recommendations as a 'test' for the CFS - an evaluation of the possibility of multi-stakeholder, collaborative processes to engage in the reasoned, nonhierarchical negotiation in the context of contentious issues related to food security.

The process for developing guidelines and recommendations in the CFS is multi-faceted. All documents, however, are negotiated in face-to-face meetings through 'Friends of the Chair' sessions during the annual, weeklong meetings of the CFS. ${ }^{21}$ At CFS 40, the Chair of the CFS (Chair) selected a delegate from Bangladesh to serve as the rapporteur or facilitator of the negotiations, which were supposed to be completed over three days' time. Conflict erupted almost as soon as the negotiations began. For twenty minutes, civil society and powerful biofuel producing states debated just the adjective that should define the link between energy and food security. Closely linked? Maybe linked? Should it be 'energy security and food

\footnotetext{
${ }^{20}$ Biofuels are also controversial because they are not energy efficient. In fact, it is highly debated whether biofuels are more sustainable than other fuel sources. Research suggests that there may somewhere between a net zero and twenty percent net gain in energy efficiency from biofuels. Biofuels promoters suggest that 'second' and 'third-generation' biofuels can promote a more sustainable future, they depend on technologies that do not yet exist at commercial scales. Moreover, biofuels are a subsidised industry that is increasingly consolidated and unevenly distributed. Fred Magdoff, 'The Political Economy and Ecology of Biofuels' (2008) 60 Monthly Review 34; The High Level Panel of Experts on Food Security and Nutrition, Biofuels and Food Security: A report by the High Level Panel of Experts on Food Security and Nutrition of the Committee on World Food Security, (2013), UN Committee on World Food Security, online: <http://www.fao.org/fileadmin/user_upload/hlpe/hlpe_documents/ HLPE_Reports/HLPE-Report-5_Biofuels_and_food_security.pdf>, 93.

${ }^{21}$ CFS 40 took place in from 7-11 October 2013. For an overview of the process as well as the history of civil society engagement, see: John L Comaroff and Simon Roberts, Rules and Processes (University of Chicago Press 1986).
} 
security'? Energy policy? The debate over the word that should define the link between food security and energy security lay at the very core of the conflict. It became immediately clear that major biofuel producing nations-Canada, the US, Brazil, and Australia-were steadfast in promoting their own biofuel industries. While they agreed to recognise the potential harmful consequences, they also sought to ensure that the text encouraged biofuels as a potential form of renewable energy and economic development. Activists sought to continually remind participants of the CFS' mandate and that any recommendations should be grounded in the prior commitments of stakeholders to protect food security.

Halfway through the first page, negotiations started to break down over a sentence that underscored 'that food security and the progressive realisation of the right to adequate food in the context of national food security should be priority concerns for all the relevant stakeholders in biofuel development. ${ }^{22}$ Civil society wished to include the names of already agreed upon human rights frameworks and guidelines that would inform this priority. In response to civil society member's push to include the right to food, the Canadian delegate stated, 'the right to food is not an agreed and established right in the same way as an international declaration.' Though the comment was surprising since the right to food lies at the very core of the CFS' mandate, it reflected the intensity of the dispute.

As time when on, the rapporteur of the negotiations increasingly began to recognise that biofuel promoting states would not compromise. He started to chasten developing countries and civil society when they continued to question the benefits of biofuels. When one African country sought to exert the same 'veto power' that powerful northern countries had been exercising throughout the negotiations, the rapporteur said that he thought that the country 'should be convinced. ${ }^{23}$ At another point he told civil society groups to come up with a more 'compromising attitude.' Consensus became a discourse that was coercively applied to less powerful countries and civil society.

Although space does not allow a thick ethnographic description of the negotiation, members of civil society were disappointed with the final product. They read a strongly worded statement in the Plenary, explaining that the negotiations 'failed to reflect the views of countries whose right to food is affected by biofuels policies' and argued that, 'the text overwhelmingly reflect[ed] the opinion of countries defending the interests of their own biofuels industry.' The Chair of the CFS responded by asking what he should do with this statement. 'How can we move forward without consensus?' he asked.

\footnotetext{
${ }^{22}$ Zero draft version of the Policy Roundtable on Biofuels and Food Security. UN Committee on World Food Security. Copy on file with author. 8-10 October 2013.

${ }^{23}$ All quotes are drawn from the author's fieldnotes of observations of the negotiations of the Recommendations on Biofuels and Food Security at CFS 40 in Rome, Italy.
} 
According to the formal rules of the CFS, only states need to vote on final standards. Yet the CFS often operates as if all stakeholders are part of the consensus. Civil society's rejection of the biofuels thus unsettled this conceit. In response, a long-time civil society participant stated that it was civil society's right to withdraw from the consensus, but that they would continue to participate in the CFS processes. The Chair looked relieved and responded that he was happy that civil society was not going to try to 'block' the process and allow it to move forward.

In analysing this negotiation, one might point to the informal rules by which powerful actors exercised power. Indeed, anthropologists have long deployed ethnographic analyses of legal processes to excavate the implicit rules and forms of power that structure legal processes. ${ }^{24}$ Certainly, both scholars and participants of deliberative processes have laboured to emphasise how such process inequalities shape unequal outcomes. ${ }^{25}$ Multiple other analyses of multi-stakeholder negotiations in the CFS and other arenas of transnational biofuel governance also have found that their participatory procedures often fail to be as authentically 'inclusive' and non-hierarchical as they claim. ${ }^{26}$ Such analyses thus prescribe a 'thickening' of deliberative processes to render them more democratic. ${ }^{27}$ Yet by focusing on political-economic power as the primary driver of political interests, such analyses may overlook the ecological entanglements that constitute power relations. Given the proliferation of collaborative mechanisms to manage conflicts between food and fuel, a new understanding of power within transnational food security governance is needed. In the final section, therefore, I introduce the concepts of 'energopolitics' and 'energopower' and suggest their utility for

\footnotetext{
${ }^{24}$ See, for example: Comaroff and Roberts, Rules and Processes (University of Chicago Press 1986).

${ }^{25}$ Taehyon Choi and Peter J Robertson, 'Deliberation and Decision in Collaborative Governance: A Simulation of Approaches to Mitigate Power Imbalance' (2014) 24 Journal of Public Administration Research and Theory 495; Jill M Purdy, 'The Role of Power in Collaborative Governance' in Richard D Margerum and Cathy J Robinson (eds), The Challenges of Collaboration in Environmental Governance: Barriers and Responses (Edward Elgar Publishing, 2016).

${ }^{26}$ For a recent view of the CFS, see: Nora McKeon, 'Are Equity and Sustainability a Likely Outcome When Foxes and Chickens Share the Same Coop? Critiquing the Concept of Multistakeholder Governance of Food Security' (2017) 14:3 Globalizations 379. For critical appraisals of biofuel governance, see: Theresa Selfa, Carmen Bain and Renata Moreno, 'Depoliticizing Land and Water "Grabs" in Colombia: The Limits of Bonsucro Certification for Enhancing Sustainable Biofuel Practices' (2014) 31 Agriculture and Human Values 455; Michiel Köhne, 'Multi-Stakeholder Initiative Governance as Assemblage: Roundtable on Sustainable Palm Oil as a Political Resource in Land Conflicts Related to Oil Palm Plantations' (2014) 31 Agriculture and Human Values 469; Greetje Schouten, Pieter Leroy and Pieter Glasbergen, 'On the Deliberative Capacity of Private Multi-Stakeholder Governance: The Roundtables on Responsible Soy and Sustainable Palm Oil' (2012) 83 Ecological Economics 42; Emmanuelle Cheyns, 'Multi-Stakeholder Initiatives for Sustainable Agriculture: Limits of the "Inclusiveness" Paradigm' in Stefano Ponte, Jakob Vestergaard and Peter Gibbon (eds), Governing Through Standards: Origins, Drivers and Limitations (Palgrave Macmillan, 2011). More broadly, for a more general critique of multi-stakeholder processes, see: Harris Gleckman, Transnational Institute, Multi-Stakeholderism: A Corporate Push for a New Form of Global Governance (2016), online: <https://www.tni.org/en/publication/multi-stakeholderism-a-corporate-pushfor-a-new-form-of-global-governance $>$.

${ }^{27}$ For a description of 'thick' and 'thin' proceduralism see: Julia Black, 'Proceduralizing Regulation: Part II' (2001) 21:1 Oxford Journal of Legal Studies 33.
} 
understanding transformations in transnational food security governance and transnational law, more broadly.

\section{Energopolitics and the food-fuel nexus}

In an era when humans are facing the ecological constraints of climate change, critical scholars have begun to re-evaluate dominant accounts of power and capitalist development by highlighting the under-acknowledged role of nature in enabling processes of accumulation. ${ }^{28}$ This move is part of a broader shift within the social sciences and humanities to recognise the ecological foundations of inequality in the age of the 'Anthropocene'-the geological epoch recently named to recognise that human activity is the primary driver of environmental transformation. Energy is at the core of these analyses. As the capacity to work, energy is crucial for labour and the production of value. Yet humans cannot produce energy on their own. As Alfred Crosby puts it, we are all 'children of the sun' that rely on plants or technologies to convert solar energy into usable carbon energy. ${ }^{29}$ Competition for carbon energy has thus served as the basis for capital accumulation and larger global political economies. Seen through an energy-focused lens, Tim di Muzio summarises that 'the global political economy is at base a solar economy whereby humans have come to monetise energy and natural resources in hierarchical domestic and international relationships. ${ }^{30}$ Scholars from multiple disciplines are thus beginning to reassess the constitutive role of energy in politics, law, and the economy. ${ }^{31}$

Recent studies have primarily focused on fossil fuels, but agriculture has been central throughout the longue duree of energy extraction and consumption. Before fossil fuels, biomass served as the primary form of fuel that powered human civilisation. In these mostly agrarian societies, control over agricultural surpluses created the material foundation for different relationships of power. ${ }^{32}$ The development of technologies that could take advantage

${ }^{28}$ Dipesh Chakrabarty, 'The Climate of History: Four Theses' (2009) 35 Critical Inquiry 197. Jason Moore describes this as a 'world ecological' approach that integrates the political economic lens of world systems theory with political ecological analyses of planetary extraction. Jason W Moore, Capitalism in the Web of Life: Ecology and the Accumulation of Capital (Verso, 2015).

${ }^{29}$ Alfred W Crosby, Children of the Sun: A History of Humanity's Unappeasable Appetite for Energy (W W Norton \& Company, 2007).

30 Tim Di Muzio, 'Energy, Capital as Power and World Order' in The Palgrave Handbook of Critical International Political Economy (Springer, 2016) 267.

31 Tim Di Muzio, Carbon Capitalism: Energy, Social Reproduction and World Order (Rowman \& Littlefield International, 2015); Andreas Malm, Fossil Capital: The Rise of Steam Power and the Roots of Global Warming (Verso Books, 2016); Hannah Appel, Arthur Mason and Michael Watts, Subterranean Estates: Life Worlds of Oil and Gas (Cornell University Press, 2015); Laura Nader, The Energy Reader (John Wiley \& Sons, 2010).

${ }^{32}$ Michael W Young, Fighting With Food: Leadership, Values and Social Control in a Massim Society (Cambridge University Press, 2009). See also: Jane Fajans, 'The Transformative Value of Food: A Review Essay' (1988) 3 Food and Foodways 143. 
of the 'buried sunshine' of carbon-dense fossil fuels transformed Western European agrarian societies and spurred colonial schemes to secure food for industrialising states, causing massive transformations in the geography of global food production. ${ }^{33}$ The industrialisation of agriculture through fossil fuel-based inputs and fuel-run machinery in the Global North deepened the relationship between food and fuel. It was not until after the 1972-1973 global food and fuel crises, however, that powerful states recognised the economic and political vulnerability caused by the 'food-fuel nexus'. ${ }^{34}$

The function of agriculture as a source of human energy and, increasingly, as transport fuel suggests that disputes over global food are substantively changing how powerful states assess the relation between food and fuel. Though political-economic accounts of power-whether in agrarian studies or those deployed in collaborative governance scholarship-emphasise the competition for capital accumulation, they often overlook the way that the material processes of extraction shape the calculative logics upon which regulation is constructed..$^{35}$ In effort to remedy this, Dominic Boyer developed the concepts of 'energopolitics' and 'energopower'. In developing these concepts, Boyer draws on the Foucauldian notion of biopolitics, which emphasises 'the specific strategies and contestations over problematizations of collective human vitality, morbidity and mortality, ${ }^{36}$ but he challenges the humancentric understandings of power and knowledge inherent in the Foucault's analysis. ${ }^{37} \mathrm{He}$ defines energopolitics as 'a genealogy of modern power that rethinks political power through the twin analytics of electricity and fuel. ${ }^{38}$ Such an intervention seeks to 'make energy a crucial part of the story of the formation of the modern subject and the constitution of the contemporary state. $^{39}$

Studies of energopolitics emphasise how socio-technical arrangements of energy extraction, production, processing, and consumption constitute contingent assemblages of political authority and expertise. ${ }^{40}$ In doing so, they reveal how energy has shaped national and global regulatory ideologies. For example, Timothy Mitchell has analysed how oil shaped the calculative

\footnotetext{
${ }^{33}$ Crosby (n 29).

${ }^{34}$ Robert Bailey, 'The "Food Versus Fuel" Nexus' in Andreas Goldthau (ed), The Handbook of Global Energy Policy (John Wiley \& Sons Ltd, 2013).

35 In agrarian studies, see, for example: Henry Bernstein, Class Dynamics of Agrarian Change (Kumarian Press 2010); For collaborative governances scholarship see: Choi and Robertson (n 26); Purdy (n 26).

36 Paul Rabinow and Nikolas Rose, 'Biopower Today' (2006) 1 BioSocieties 195, 197.

37 Boyer (n 6).

${ }^{38}$ Boyer, 'Energopower: An Introduction' (n 6) 325. See also Dominic Boyer, 'Energopolitics and the Anthropology of Energy' (2011) 52 Anthropology News 5, 5.

39 Imre Szeman, 'Conclusion: On Energopolitics' (2014) 87 Anthropological Quarterly 453, 459.

${ }^{40}$ See, for example: Douglas Rogers, 'The Materiality of the Corporation: Oil, Gas, and Corporate Social Technologies in the Remaking of a Russian Region' (2012) 39 American Ethnologist 284; Catherine Alexander and Joshua $O$ Reno, 'From Biopower to Energopolitics in England's Modern Waste Technology' (2014) 87 Anthropological Quarterly 335; Jennifer Richter, 'Energopolitics and Nuclear Waste: Containing the Threat of Radioactivity' (2017) 30 Energy Research \& Social Science 61.
} 
logics of the post-war Keynesian welfare state. As he explains, the availability of seemingly endless amounts of oil enabled post-war economic theorists such as Keynes to bracket natural resources and flows of energy, which had previously thought to have been finite and instead build a modern science of economics based on money and prices. ${ }^{41}$ Mitchell argues that these calculative logics enabled the 'economy' to emerge as an independent sphere of expert knowledge and management, thereby facilitating the rise of the US regulatory state. While the materiality of oil-its abundance, location, and ease of transport-helped shape the forms of knowledge that allowed for administrative control, food also played a key role. ${ }^{42}$ Fossil fuel-based inputs provided the agricultural surpluses that were used by the US as a tool of peace (and warfare).

Together, the food-fuel nexus of the mid-twentieth century helped to form what Wolfgang Friedman called the 'international law of cooperation'. ${ }^{43}$ The post-war order was envisioned as a global economy regulated by institutions modelled in the image of the Keynesian welfare state-premised on national economic development, import-substitution industrialisation, and agricultural protection. ${ }^{44}$ The formation of transnational food and agricultural institutions thus helped to inscribe the Keynesian-Fordist development project into the post-war international order.

Yet as early as the 1950s, struggles to maintain control over oil foreshadowed a normative set of transformations that would become more dominant in later decades. During this period, Philip Jessup observed what he described as 'transnational law,' a new form of legality that combined public and private law and incorporated both states and non-states. ${ }^{45}$ Jessup's use of examples from agreements and arbitrations between nation-states and multi-national oil corporations to analyse this new legal form is often overlooked. In the bid to secure their oil resources British and American states elevated multinational oil corporations' status into an almost quasi-state, embracing an 'international law of contract' in which states and corporations were aligned as

${ }^{41}$ Timothy Mitchell, Carbon Democracy: Political Power in the Age of Oil (Verso Books, 2011); Christophe Bonneuil and Jean-Baptiste Fressoz, The Shock of the Anthropocene: The Earth, History and Us (Reprint edition, Verso, 2017).

${ }^{42}$ Mitchell notes the important role of agriculture, explaining, 'We think of industrialization (and the democracy that followed) as an urban phenomenon based on fossil fuels, but it depended on an agrarian and colonial transformation based on organic forms of energy'. Mitchell (n 41) 16.

43 Wolfgang Friedmann, The Changing Structure of International Law (Columbia University Press, 1964).

${ }^{44}$ As Anne-Marie Slaughter explains, in its early formation, Roosevelt hoped to design the Food and Agriculture Organization (FAO) in the model of a US regulatory agency. She writes, 'In 1943, Roosevelt envisioned the conferences of the Food and Agriculture Organization as prototypes for a series of permanent international agencies in social and economic fields'. Anne-Marie Burley-Slaughter, 'Regulating the World: Multilateralism, International Law, and the Projection of the New Deal Regulatory State' in Robert Howse (ed), The World Trading System: Critical Perspectives on the World Economy (Routledge, 1998); See also, Amy LS Staples and Amy L Sayward, The Birth of Development: How the World Bank, Food and Agriculture Organization, and World Health Organization Changed the World, 1945-1965 (Kent State University Press, 2006).

${ }^{45}$ Philip Jessup, Transnational Law (Yale University Press, 1956). 
equal private actors. ${ }^{46}$ When the world faced oil and food crises in the 1970s, the 'transnational situations' observed by Jessup became increasingly commonplace as concern over oil propelled the ascendance of neoliberalism. Indeed, the oil shocks were used by neoliberal economists as evidence for what they argued was the failure of Keynesian regulation. ${ }^{47}$ Both Keynesianism and neoliberalism were thus shaped by energopolitics; Just as Keynesian ideology was enabled by the calculative logics of abundant energy, neoliberal theory attempted to externalise the increasingly recognised scarcity of energy through the price system. Beginning in the late 1970s and 1980s, this led to a more market-oriented, and corporate consolidated system of global food production and provisioning.

By the 2000s, the food-fuel nexus facilitated yet another set of normative transformations. The increasing demand for biofuels and the pressures this put on agricultural land, especially through land grabs, caused a global food crisis that revealed a fundamental conflict between food and fuel. ${ }^{48}$ To mediate this conflict, collaborative and multi-stakeholder models emerged as a new common-sense for transnational food and environmental governance. ${ }^{49}$ By including civil society and social movements, this participatory paradigm created the possibility of democratising the governance of global food. In fact, collaborative multi-stakeholder models of governance have become most widespread in fields related to energy: food, agriculture, and mining. ${ }^{50}$ Yet collaboration, is not restricted to environmental conflicts. In response to the failure of neoliberal forms of coordination, Annelise Riles suggests that collaboration has become increasingly a 'template for social and political life, as well as market activity. ${ }^{51}$

While scholars have described the organisational diffusion of multi-stakeholder models as an expression of the politics of sustainability, ${ }^{52}$ they can also

${ }^{46}$ Antony Anghie, Imperialism, Sovereignty and the Making of International Law (Cambridge University Press, 2007) 229-34.

47 The development of the field of resource economics, played an important role in defeating Keynesian economics by developing new market mechanisms including an oil futures market on the New York Mercantile Exchange and carbon markets that could serve to coordinate the petro-economy. See Timothy Mitchell, 'The Resources of Economics' (2010) 3:2 Journal of Cultural Economy 189. In addition, Sandy Smith-Nonini traces the ways in which the oil crisis and the petrodollars that were generated from it enabled neoliberalism to emerge. Sandy Smith-Nonini, 'The Role of Corporate Oil and Energy Debt in Creating the Neoliberal Era' (2016) 3 Economic Anthropology 57.

${ }^{48}$ Philip McMichael, 'Biofuels in the Food Regime' (2010) 37:4 The Journal of Peasant Studies 609; Marc Edelman, Carlos Oya and Saturnino M Borras JR, 'Global Land Grabs: Historical Processes, Theoretical and Methodological Implications and Current Trajectories' (2013) 34:9 Third World Quarterly 1517.

${ }^{49}$ Neil Gunningham, 'The New Collaborative Environmental Governance: The Localization of Regulation' (2009) 36:1 Journal of Law and Society 145.

50 MSI Integrity and Duke Human Rights Center at the Kenan Institute for Ethics, The New Regulators? Assessing the Landscape of Multi-Stakeholder Initiative (2017), online: <https://msi-database.org/ data/The\%20New\%20Regulators\%20-\%20MSI\%20Database\%20Report.pdf>.

${ }^{51}$ Annelise Riles, 'From Comparison to Collaboration: Experiments with a New Scholarly and Political Reform' (2015) 78 Law and Contemporary Problems 147, 153.

52 Klaus Dingwerth and Philipp Pattberg, 'World Politics and Organizational Fields: The Case of Transnational Sustainability Governance' (2009) 15:4 European Journal of International Relations 707. 
be understood as a product of energopolitics. For the multi-stakeholderisation of the food-fuel nexus represents an effort to re-internalise planetary limits back into socio-economic forms of regulation that were once excised in Keynesian and neoliberal regulatory forms of regulation. However, through the multi-stakeholder model, food and fuel are constructed as a set of equivalents that assumes a consensus can be reached between these two goods. By reinternalising the environmental limits through the bargaining model of multi-stakeholder governance, the contradiction between food and fuel is diffused and the relation between them is reconstructed as complementary.

An energopolitical account of collaborative governance thus reveals how material processes of energy extraction and consumption shape how contestation related to the food-fuel nexus is constituted. In this context, energopower operates through both construction of its subjects and as a process of dispute management. First, multi-stakeholder governance constructs 'stakeholders' as formally equal parties to a conflict. Rather than recognising the historicallyshaped hierarchies and differentiated responsibilities that have resulted from uneven energy consumption and emissions, collaborative arrangements seek to transcend inequalities between stakeholders through 'authentic' and 'inclusive' dialogue. However, the biofuel negotiation described above unsettles this conceit. This was clear from the rapporteur's efforts to coerce less powerful countries and civil society actors into being 'more compromising.' Yet only certain actors needed to adopt a more compromising attitude, illuminating the implicit hierarchies of power underlying the multi-stakeholder process.

Second, multi-stakeholder processes reconstitute deeply political conflicts over energy-fuelled inequalities as technocratic problems that can be solved through consensus-based solutions. Throughout the negotiations, the rapporteur constantly echoed the refrain that 'we need to get to consensus' in attempt to diffuse antagonism between stakeholders. This techno-managerial approach to mediating conflict has thus been described as 'post-political. ${ }^{53}$ The post-political frame emphasises the contradiction that while climate change, fossil fuels, and food security each have become highly politicised and contentious issues, energy-fuelled conflicts of profound distributional concern are being managed through processes that depoliticise them. Such an analysis suggests that collaborative forms of governance serve to repress the political ecological contradictions of capital, just as was accomplished through previous regulatory ideologies.

As multi-stakeholder forms of governance continue to proliferate, an energopolitical lens thus connects seemingly disparate sites of contestation to

\footnotetext{
${ }^{53}$ Erik Swyngedouw, 'Apocalypse Forever? Post-Political Populism and the Specter of Climate Change' (2010) 27:2-3 Theory, Culture \& Society 213, 225; see also: J Duncan, 'Governing in a Postpolitical Era: Civil Society Participation for Improved Food Security Governance' in David Barling (ed), Advances in Food Security and Sustainability, vol 1 (Elsevier, 2016).
} 
larger struggles over carbon extraction, emissions, and consumption. Indeed, today, multi-stakeholder processes are increasingly proffered as a best practice for managing ecological conflicts; both the Sustainable Development Goals and the CFS are promoting multi-stakeholder partnerships. ${ }^{54}$ While political-economic approaches suggest that collaborative processes may reproduce existing power relations, an energopolitical lens reveals how they are both constituted by and constitutive of the broader political ecologies responsible for climate change. For as climate change poses an increasing threat to global food security, an energopolitical lens connecting larger struggles over carbon-fuelled climate change is critical.

\section{Conclusions: food, fuel, and the political ecology of transnational law}

Transnational food security governance is an increasingly important site of study for transnational legal scholars. Struggles over food and agricultural regulation in the national context have long been constitutive socio-legal processes through which new understandings of public and private are constructed. As these conflicts are projected into transnational arenas, they become formative in reshaping relations between state, society, and markets. Yet the rise of biofuels at a time of increasing concern over fossil fuel-produced climate change also serves as a reminder of the enduring role of the food-fuel nexus and provides an impetus to rethink dominant accounts of power within the law and politics of global food security. Following recent political ecological analyses of global capitalism, I have argued that understanding the food-fuel nexus within larger global processes of energy extraction, processing, and distribution illuminates the ecological foundation of contemporary power asymmetries. Drawing on such an approach reveals how the proliferation of new multi-stakeholder forms to manage the mutually dependent but contradictory relationship between food and fuel reflects a larger process of energopolitical transformation.

New forms of multi-stakeholder governance are premised on the assumption that participation and non-hierarchical collaboration can produce new compromises between competing social, economic, and environmental values. Indeed, the development of this normative form in response to both neoliberal welfare state withdrawal as well as new concerns over the global public good of the environment, is a product of larger energopolitical and political-economic transformations. Yet as both my observations of the biofuel negotiation in the CFS as well as numerous studies of biofuel 'Roundtables'

\footnotetext{
${ }^{54}$ See SDG \#17 (17.16 and 17.17) See: http://www.un.org/ga/search/view_doc.asp?symbol=A/RES/70/ 1\&Lang=E. In addition, the High Level Panel of Experts of the CFS recently undertook a study of 'Multi-Stakeholder Partnerships to Finance and Improve Food Security and Nutrition in the Framework of the 2030 Agenda'. See: http://www.fao.org/3/CA0156EN/CA0156en.pdf.
} 
suggest, ${ }^{55}$ these arenas often serve as processes through which powerful biofuel producing states and multinational corporations seek to legitimise their economic and energy interests. By framing concerns over food security and energy security as equivalent values, these processes depoliticise the tension between food and fuel thereby concealing the ways in which access to and control over energy serve as the foundation of modern political power. Analysing transnational food security governance from the vantage of energopolitics thus suggests that collaborative processes are often themselves compromised.

Ultimately, as collaboration becomes the sine-qua-non for sustainability in an age of climate change, an energopolitical analysis is essential. For as we enter the new geological epoch known as the Anthropocene, new analytical tools are needed to integrate nature back into our accounts of how power operates. Towards this end, energopolitics offers a new conceptual tool for this analytical programme, for which transnational legal scholars are now beginning to advocate. ${ }^{56}$ By connecting disparate sites of conflict, an energopolitical approach illuminates the shifting operation of global power and moves us towards a greater understanding of the political ecology of transnational law.

\section{Acknowledgements}

I would like to thank Marie-Claire Foblets, Priscilla Claeys, Amy Cohen, Julia Dehm, James J.A. Blair, Leon Castellanos-Jankiewicz, and Marta Morvillo for comments on various versions of this paper.

\section{Disclosure statement}

No potential conflict of interest was reported by the author.

\section{Funding}

Research funding for this paper was generously provided by a National Science Foundation Directorate for Social, Behavioral, and Economic Sciences, Law and Social Science Program, Doctoral Dissertation Research Improvement Grant (SES\# 1323743).

\footnotetext{
${ }^{55}$ See (n 26) for example Cheyns (2011).

56 See Julia Dehm, 'Post Paris Reflections: Fossil Fuels, Human Rights and the Need to Excavate New Ideas for Climate Justice' (2017) 8 Journal of Human Rights and the Environment 280; Christine Parker and Fiona Haines, 'An Ecological Approach to Regulatory Studies?' 45:1 Journal of Law and Society 136; Luis Eslava, Usha Natarajan and Rose Parfitt, '(Post)Revolutionary Interlinkages: Labour, Environment and Accumulation' (2013) 4:1 Transnational Legal Theory 108; Usha Natarajan and Kishan Khoday, 'Locating Nature: Making and Unmaking International Law' (2014) 27:3 Leiden Journal of International Law 573.
} 